\title{
Television, Tape, Internet: Dialectics of the Postmodern in the U.S. from 1950 to 2000
}

\author{
Mark Poster
}

The term "postmodern" may be understood as the cultural construction of reality in the midst of the modern. Jean-François Lyotard depicted the postmodern above all as the collapse of modern metanarratives, especially that of progress. In contrast, Fredric Jameson outlined the postmodern as the culture of late capitalism, providing a convincing portrait of it as lacking in depth, stressing fragmentation, waning in affect, and resorting to a style of pastiche. Jameson also pointed to what he considered a disjuncture of space and the body, most notably in architecture, and what is often overlooked in accounts of his work, a certain reliance on technology (6). Since these writings of the late 1970s and early 1980s the postmodern thesis has undergone heavy criticism in some quarters but also fruitful integration into discourse in others. I shall resume the question of postmodern culture with particular attention to the relatively overlooked suggestion of Jameson that it bears a special relation to technology. I shall argue that American culture in the second half of the twentieth century may be seen as a series of turns toward some version of a postmodern culture in particular through its relation to information machines. The dissemination of these machines, beginning with television, introduces a mediation

Mark Poster is Director of the Film Studies Program and a member of the History Department at the University of California, Irvine. He has a courtesy appointment in the Department of Information and Computer Science. He is also a member of the Critical Theory Institute. His recent books include What's the Matter with the Internet? (Minnesota, 2001), The Information Subject (Gordon and Breach Arts International, 2001), Cultural History and Postmodernity (Columbia, 1997), The Second Media Age (Blackwell, 1995), and The Mode of Information (Chicago, 1990). 
in the construction of cultural reality. They reconfigure the basic constituents of culture-the relation of the body to mind, human to non-human, space and time, subject and object.

After the trials of the Great Depression and World War II, Americans moved to the suburbs. Ensconced in attached and semi-attached single residence family homes, Americans pursued the virtues of middle-class life with a compulsive sense of determination. The deprivations, conflicts, and horrors of the 1930s and 1940s were left behind in favor of a single-minded, forward-looking gaze at a future of virtue. Americans, by and large, disavowed all the filth and evil of the earlier decades in a collective psychological embrace of the values of the heterosexual, white, private nuclear family. From the great collective actions of working class struggle and the New Deal in the 1930s and the sacrifices and commitments of the nation united in battle against fascism, Americans retreated into what they thought was the privacy of their homes. A vision of small town middle America in the style of Disneyland's Main Street was transposed into the new tract homes cropping up like weeds across the continent.

If Americans needed any encouragement to withdraw from the public sphere, the nation-state and the economy gave them plenty. The state initiated an extensive, paranoid campaign against communism, searching out and persecuting enemies everywhere, encouraging the digging of underground shelters, compelling schoolchildren to hide under desks during air raid exercises. Meanwhile, industrialists lobbied for the automobile, for building interstate highways, for destroying public transportation systems. They manufactured and promoted an array of domestic appliances, filling all those suburban homes with time-saving and convenient machines. With Europe busy recovering from war-time ravages, the U.S. flexed its political muscle across the globe, working out a cozy, if ideologically conflictual, arrangement with the Soviet Union that effectively divided the world and stabilized it against all comers. Within the "free" zone, American products, along with its ideology, prevailed.

But this rush back to a future of modern, suburban normalcy that had never existed included one aspect that would set American culture going in a decidedly new direction. The television set entered the living room of Americans at a truly breakneck pace: from 1948, when the first national programs were broadcast, until 1955 , a full $60 \%$ of homes included TVs. And by 1960 , the figure rose to an amazing 90\% (Spigel). Unlike the earlier culture industries of film and radio, television promoted a culture in the home that dissolved the family values it was intended to secure and promoted as fostering. Film, by contrast, was a cultural event outside the home, very much like theater; and radio, at least in the popular imagination, appeared to amplify family togetherness and shared experience even though it commercialized family space (Douglas). Each in their own way, film and radio reinforced the boundary between the public and the private. Television, on the contrary, with its powerful combination of video and audio, inserted into American living rooms its own culture, the world of consumption, a space of signification and meaning that was neither private nor public. Perhaps because it emerged at a time 
of great economic abundance-even so characterized by John Kenneth Galbraith in The Affluent Society - television from the outset fostered consumerism. It did so with the crucial assistance of the Federal Communications Commission abetting national networks in their promotion of products for a national market (Browne). Relentlessly, network television disseminated the culture of its products in its ads, in the content of programs, and in the structure of its schedule. Into the work ethic of industrial American society entered the serpent of the consumer as hero/heroine and as a new subject position. Against the ideal of Promethean virility of the modern man came the impulsive, feminized identity of the consumer.' Surely fragments of a feminized consumer antedated the 1950s, as advertisers in the 1920s, for example, became aware that the person who did the shopping was female and their promotions needed to reflect that fact (Marchand). Even back in the later half of the nineteenth century soaps, hair lotions, and medicinal pills of all kinds entered the market enshrouded with publicity (Richards). Indeed, historians are not embarrassed to trace the origins of consumer society back to the eighteenth century (McKendrick et al.). Yet a certain density of cultural practices awaited the dissemination of television into the home before the constitution of the subject as consumer could occur. ${ }^{2}$

Culture theory from the late 1940s to the mid-1960s did not look with favor upon television. Solidly within a framework of high and low art, theorists designated television to the level of the mass and generally either disregarded it or treated it with contempt or dismay. This is true of all the leading theorists of the period: Lionel Trilling, Edmund Wilson, and Northrop Frye in literature; Clement Greenberg in art criticism; Seymour Martin Lipset in political science; Daniel Bell, William Whyte, and David Riesman in sociology. Riesman's highly influential The Lonely Crowd painted a bleak portrait of the emerging suburban corporate culture, with television as one contribution to the scene. One might say that the appreciation of television by American theorists fit within the techno-phobic framework set forth by Jacques Ellul, whose condemnation of the new machines appeared in English in 1964. The lone figure to challenge the dominant position was of course Marshall McLuhan, a Canadian literary critic whose theory of the media outraged and repelled most academic and theoretical writers on popular culture. The Gutenberg Galaxy and Understanding Media brought a potential interest in television and the media more generally that might be difficult to disregard, though most managed quite successfully to continue to do just that.

The world of work structured a subject in a linear trajectory of the career, punctuated by days, weeks, months, and years with projects to be completed and paychecks that repeatedly closed the narrative of the life cycle. Industrial labor collaborated with the modern subject position as centered, rational, and autonomous. The media of print and film confirmed, deepened, and extended the modern subject as a coherent individual with stories that were completed, events that were explained, and a world that moved toward progress and betterment. The individual was an agent whose own life had a particular direction which could be harmonized with the direction of history. Encouraged and cajoled to leave their wartime occupations, American women entered the suburban home to organize it and the lives of 
their children in a sexual division of labor that was constraining to be sure but also provided them a sense of connection with the modern. As alter egos to their husbands and as managers of the home women too might believe, as the dominant discourse insisted, that they were agents of history.

The structure and content of television introduced a new pattern into the lives of modern Americans in the 1950s. A continuous flow of images worked against the temporality of cultural objects as demarcated in time, and a continuous interruption of programs by commercials undermined the unity of the program (Williams). An imaginary geared to the aesthetics of coherence was punctured with regularity by fantasies of gratification through consumption (Houston). The linear narrative of Oedipal desire was displaced by a schizophrenic narrative of multiplicity, of fragmentary yearnings, opening the subject to less centralized patterns of identification. The political economy of commercial network broadcasting introduced into the most privatized nuclear unit in history an outside, a mediatized public world with a post-Oedipal libidinal structure.

The content of ads as semiological constructs also worked against the grain of the modern subject and was also imbricated in the form of television media. Commercials attached signifiers to signifieds, words and images to meanings, in a manner at odds with the language of everyday life. Motivated to sell commodities, advertisers strove to transform the mundane pleasures of the product into more profoundly gratifying experiences. Ordinary objects were invested with desirable attributes that otherwise had no obvious relation to them. What could not be said about a product in face-to-face contact, at least with a straight face, could be depicted as such in the small space of the television screen. TV ads incited desire and solicited the viewer to a process of identification with the brand and the model, while simultaneously interpellating the subject as consumer. The culture of simulations emerged in the privacy of the home just at the time when everyone thought they were safe and clean, middle-class and American, white and God-fearing. Behind the back of the threat of communism, the modern subject was infiltrated by a postmodern culture of language and desire even more effectively than by Bolshevism. If world politics were stabilized in detente, arms race, and Cold War, culture was being revolutionized in the micro-politics of the home.

In the 1970s the public sphere was animated by a new set of conflicts-the civil rights movement challenged racism; the anti-war movement challenged U.S. imperialism; the feminist movement challenged patriarchy and sexism; the ecology movement challenged the wastefulness of producers and consumers; the counter-culture challenged suburban utopias; the gay and lesbian movement challenged heterosexism. Altogether these new social movements brought an anti-authoritarian mood into the forefront of American political life. In the early 1970s, one might say, modern culture was reinvigorated by this frenzy of leftist activism. It appeared that history again was moving in a progressive direction, that structures of domination were being contested that previously had not occupied center stage in the political arena, that it was possible to find personal coherence in political agencyin short, that history made sense. A host of ideologies emerged which promoted 
the democratizing positions, and these were bolstered by the progress of decolonization and by the spread of socialist regimes in Europe.

The 1970s also saw the importation of European theories of culture that afforded new approaches foreclosed by the limitations of the dominant liberal frameworks of the 1950s and 1960s. This sharp break with the ideas and trends of the earlier decades was effected by younger, less established people who had experienced the heady politics of the New Left. In the late 1960s and early 1970s European theory became available for the first time since World War II. It was brought to the United States by graduate students and young academics in journals and book translations. Telos, Sub-stance, Semiotext(e), and New German Critique transformed the theoretical scene with major works by the Frankfurt school and French neo-Marxists, structuralists, and poststructuralists. Martin Jay's Dialectical Imagination and my own Existential Marxism in Postwar France gave overviews of perspectives on politics, society, and culture that initiated broad interest in continental thought. A rich debate began in the United States about contemporary culture in which French and German thinkers were combined (such as Habermas and Baudrillard on communication theory), a mixture that did not exist on the continent, where the Rhine was an unsurpassable boundary. In this intellectual context a new type of thinking, "critical theory," was born, which contributed greatly to opening new perspectives on culture and technology. At the same time British thought entered the American discussion most notably through the journal New Left Review, eventually introducing a left theory of the popular known as "cultural studies." By the mid-1980s, cultural studies and critical theory combined with feminist, queer, and postcolonial theory in a complex articulation of approaches to culture.

The information machines that spread most numerously during these years were the photocopy machine, the fax machine, the audio cassette recorder, and the video cassette recorder. These technologies appeared also to foster a massive decentralization of information, putting into the hands of the ordinary individual the ability to produce copies of cultural objects. If the large world of politics shifted toward democracy in the 1970s, so the small world of the individual appeared also to empower people in a salutary, decidedly modern, direction. One could, for a relatively small amount of money, make or obtain copies of the major media - print, phonographs, radio and television broadcasts, prerecorded audio- and videotapes.

One other information machine began to enter the home in the 1970s: the telephone answering machine. This device also appeared to enhance the powers of the agent, the modern rational subject. No longer was the individual behaviorally conditioned, like a salivating dog, to the ring of the telephone. The machine could answer the call, recording the message on audiotape. But the machine also responded when its owner was not at home, introducing into daily life a new element of virtual presence. Radio and television extended the voice and image through space, affording remote presence. The tele-presence of the broadcast media moved sounds and images to the individual — they did not alter the individual's presence in space so much as extend the ears and eyes, as McLuhan maintained, to distant locations (Understanding Media). The telephone enabled individuals to speak 
across distances covered by wires (and later radio signals), but again the caller or receiver was at a fixed point in space, one associated with a specific telephone number. The telephone answering machine, however, enabled the individual to receive an audio message as if they were at the location of the telephone number, but in fact might not be there. And with a remote retrieval system, one could hear the message on the tape from a distant location, now multiplying the position of the body in space. A similar effect is achieved on shopping channels when an individual phones in and hears their voice coming from the television while they speak into the telephone. Or when someone phones a radio talk show and hears their voice coming from the radio while speaking into the phone. In these cases-which have become commonplace-the person occupies several positions at the same time. Such multiple positioning, one could argue, subverts the visual/aural body as a subject, as a definite point in Euclidean space from which perspective, in its Renaissance version, can be attained and stabilized. With these technologies, postmodern culture takes another step toward realization.

In the 1970s, the art world also witnessed the beginnings of the postmodern. Whatever anticipations there may have been in the nineteenth and early twentieth centuries, the assault upon the high/low barrier in art may usefully be dated to the 1970s. Rather than a high modernism that transgressed the forms of autonomous art, postmodern art registered the spread of information machines and the formation of the subject as consumer. Pop art, previously an oxymoron, explored the same aesthetics that television viewers experienced thousands of times a year. The commodity as object and the celebrity (the commodity as person) became the materials of aesthetic works. What was shocking to a modernist sensibility - for example, the presence of a work of Plato in an airport convenience store-was becoming commonplace as the markers of culture were drastically shifting and reforming (Marcuse). If modern cultural works derived their energy in part from their resistance to commodification and market principles (even though they were complicit with them if not absorbed by them), postmodern culture worked in and through the commodity as the locus of identification and subject construction.

At the level of discourse the shifting configuration of cultural formation was registered by poststructuralist theory. The term postmodern is an impossible one for poststructuralism and most of the major figures in this movement-from Baudrillard and Foucault to Derrida and Deleuze - refused it, as they did the term poststructuralism itself, by the way. The history of poststructuralism, in addition, is itself postmodern, as discourse traveled from France and to some extent from Germany, Italy, and England to the United States, becoming altered in the process but at the same time extended and expanded. Poststructuralism took the insight from Nietzsche that there was a need for a critique of values at the level of culture, as well as the insight from the structuralist linguists and anthropologists that the subject did not simply deploy language instrumentally as an enhancement of agency but was at the same time deployed by it, formed into cultural positions. In modernity, Foucault and others contended, this position was that of the subject, the centered, autonomous, Oedipal agent. A cultural critique must then account for the process of this formation as a step in its possible, future reformation. 
The 1970s then saw an ambivalent movement both toward a renewed modernist culture of the New Left and the new social movements and an opposite tendency in some information machines, in some art currents, and in poststructuralist theory. A richer articulation of the postmodern awaited the 1990s and the diffusion of digital information machines. At the theoretical level a concept of culture that overcame the high/low distinction was still lacking. Among critical theorists, even of the postmodern persuasion (like Lyotard and Jameson), a divide prevailed between literature and film on the one side and television on the other. Baudrillard was the exception to the general neglect of an anthropologically inspired understanding of culture, and the scorn with which he was regarded by other theorists proves this point. So does the belated recognition of the importance of the British cultural studies school. The dominant figures of theory in the 1970s-Jameson, Lyotard, Derrida, Foucault, Deleuze, Lacan—shied away from popular culture. But things would change by the late 1980 s as a new generation of cultural theorists, men and women raised in front of the tube, would understand culture in a way that fostered an appreciation of technology. The old world sense of cultural depth that so marked Adorno and Horkheimer's "The Culture Industry" began to appear irrelevant as mediated cultural objects drenched the landscape.

The collapse of the Soviet Union, the Eastern European Communist States, and the reunification of Germany in 1989-1990 took the world, especially the United States, by surprise. The role of the media in these events was by no means negligible. In the long-term, the broadcasts of Radio Free Europe and U.S. television and, in the short-term, the spread of information about the unfolding events from nation to nation both prepared and hastened the process of transformation. Some analysts have argued that the crumbling of the Soviet bureaucracy itself was in good part due to its policy of restricting information access, slowing the introduction of information machines from photocopiers to recordable VCRs and finally to computers (Castells). A top-down planned society cannot endure in an age of decentralized information flows, this argument maintains. However one explains the fate of communism in the old world, it certainly upset the mental apple-cart in the new. The United States found itself without an enemy and in control of the world, not a good position for a nation with a forty year policy of paranoia. To be sure, the engine of ideology quickly produced new demons-Islamic fundamentalists and terrorists more generally - but this cultural creation had more the feel of a simulation than the earlier "evil empire." Now, of course, the United States is back on track, with a dangerous enemy to be captured "alive or dead," in the words of President George W. Bush. However, in the struggle against networked Al Qaeda terrorists, the United States could not act alone and proceeded only with the agreement of a wide number of other nations. Globalization, it was revealed in the War in Afghanistan, had developed to the point where a planetary empire was emerging, a very different configuration of forces from that of the bi-polar Cold War (Hardt and Negri).

The events on other continents were by no means irrelevant to developments in the United States above all because of the rapid globalization of the world, if one may use that term, in the 1990s. In this decade economic and demographic global- 
ization were unprecedented. The mixing across the planet of corporate structure, work, finance, commodities, and people proceeded apace. While these trends certainly affected the emergence of postmodern culture, for reasons of space I shall restrict my analysis to yet another aspect of globalization that may be considered more immediately relevant to my topic: the birth and dissemination of networked computing.

The Internet installs a new kind of space, that of the virtual. It continues the tendency of mankind perhaps from the outset but certainly since print to duplicate reality, to create a second order of culture, one apart from the synchronous exchange of symbols and sounds between people in territorial space. Print, telegraphy, phonographs, film, radio, and television all enable mediated culture, the breaking up of the unity of time and space in the exchange of cultural objects between individuals and groups. But each of these technologies of information suffers from material constraints on their ability to violate phenomenological time and space. None of these media offer cultural objects everywhere and at any time. The process of the production and distribution of culture in these media operate within the domain of the analogue and within the logic of scarcity. Copying and storage are expensive and, in varying degrees, difficult. Great strides were made during this first media epoch to facilitate the multiplication of objects cheaply and democratically. From pirated printing in the seventeenth century to citizen band radio, pirate radio, and audio- and videocassette duplication in the twentieth, the control of analogue media has always been partial at best. Yet the analogue mode of information lent itself to control by the modern institutions of the nation-state and the corporation.

The Internet combines a planetary, decentralized communication system (telephone wires, communications satellites, radio frequencies) with digitized information. Cultural objects are thereby shifted from a Newtonian, analogue regime to a quantum, digital regime. Copying, storage, and distribution are in principle costless, although pre-existing economic regimes may impose their costs just as Feudal toll collectors imposed costs on trade in the early period of capitalist commerce. The virtual order of cyberspace brings into proximity distant locations and implodes into instantaneity sequential events. The long-term cultural consequences of this innovation must be devastating for the modern, bearing in mind, however, a single but crucial caveat. No technology results in automatic consequences. All instruments are subject to change in their structure by their users, even as they alter those users. To predict the birth of the postmodern as a result of the Internet is simply absurd. Yet one cannot ignore the potentials of the technology even as it evolves from a university-based research tool to a vast retail store and financial instrument to a tool of military institutions and governments to a warehouse of erotica to a pick-up spot.

The on-line individual is heavily mediated by the interface of globally networked computers. This individual must know that his or her consciousness, cognition, and emotion are minuscule in comparison with what is at the other side of the screen. Just as the user is empowered by the tool of the Internet in a fully modern sense, so this user is also fragmented, dispersed, decentered, and 
marginalized by it in a fully postmodern sense. Like the consumer of the $1950 \mathrm{~s}$, the Internet user holds a position which is difficult to characterize as modern. The user as subject position is displaced from the privileged perch of res cogitans and brought within the rough domain of res extensa. At one with the network of wire tentacles and electronic pulses, the user is no longer a subject in the modern sense of the word, no longer one who stands under and controls the object. At best one might say that user and interface together form a new configuration of the subject, one characterized not by the overdetermination of its desires but by the underdetermination of its identity.

For the modern subject, identity is formed in the early years through the Oedipus complex, bolted to the self at the unconscious, libidinal level. Once established as an ego, the individual rounds out the process of becoming a subject through its engagement with discursive regimes and ideological apparatuses starting with schooling. Interpellated by teachers as a student, the individual recognizes him/ herself through a maze of tests. During this process, subjectivation as rational autonomy is continually reinforced through assimilation into cultural figures of economic rationality, political citizenship, and the law's "reasonable man." Print media also function as a correlative to the discourses of subjectivation (Warner).

As we have seen, the cultural force of the modern subject begins to unravel in the 1950 s with the practice of television viewing and the solicitation of individuals through the virtuality of the screen into the position of being consumers. The laser-like focus of Oedipal desire is replaced by the scattered longings for commodities. By the 1990s, with mediated culture in full hegemony and high/low distinctions obliterated, with the borders between producer and consumer in the domain of culture slowly eroding in favor of the digital user, the shattered remnants of the modern subject become barely visible on the horizon of culture. Instead, identity emerges as a construct. With the thick interface of networked computing, identity is no longer misrecognized in the mirror because there remains no body to reflect into it. Misrecognition becomes self-subjectivation. The user defines him/ herself in what can only be inauthenticity. The only origin to the user's identity in cyberspace is the typed signs that perform its character. Identification only occurs in the screen and is lost as soon as the user turns back to real life.

Bits and pieces of the modern subject continue, even dominate, in cyberspace. Compulsive instrumentalism colors the spaces of stock trades and get-rich schemes. And users who mistake their consciousness for reality, who presume to create themselves, to form their own identities, enter the same ideological discourse as consumers who think they are fulfilled and free in their choice of commodities. These gestures of recognition tie networked computing to the modern, but they do so always at the cost of disavowing the machinic relation. If the user holds onto the link with the interface, reflexively examining the scene of subjectivation, a different interpretation becomes more likely. The assemblage of user-network is a cultural mechanism for restructuring the figure of the subject, one in which the process of cultural production and the process of subjectivation are concurrent, continuous, and unending. To the extent that networked computing becomes a discursive apparatus of this order, to the extent that the mediation it inscribes resembles even 
roughly this form, then something monstrous, something postmodern, is likely to emerge from it. It is difficult to say what precise shape this new postmodern culture is likely to take and it is truly hazardous to speculate about it. But surely new cultural forms are on the horizon that have networked computing as a condition of their emergence. This means that the medium of art will be digital; that its interface will be the screen; that its formation will include the possibility of collective production; that its reception will include the possibility of its recreation; that its medium will be at once textual, aural, and visual; that its context will be global. Each of these features involves to a greater or lesser extent a break with earlier conditions. If Benjamin foresaw new possibilities for art with the introduction of the cinematic apparatus, surely the prospects for change are even greater for the work of art in the age of digital (re)production.

Throughout this essay I have unashamedly periodized. I have put things in their modern and postmodern places. This commonplace historical practice is of course completely at odds with a postmodern sensibility. The paradox of my essay is that the delineation of the postmodern can only occur through modern discursive practices. From a modernist perspective this fact is a performative contradiction, as Habermas would say. From a postmodernist stance, paradox is the condition of utterance.

\section{Notes}

1 This assertion is fundamental to the cultural study of television. It was introduced by Andreas Huyssen and Beverle Houston. See also Joyrich; Morse; Modleski.

${ }^{2}$ See the persuasive study by George Lipsitz on the relation of the family, television, and consumerism.

\section{Works Cited}

Adorno, Theodor W., and Max Horkheimer. Dialectic of Enlightenment. Trans. John Cumming. New York: Continuum, 1972.

Benjamin, Walter. "The Work of Art in the Age of Mechanical Reproduction." Illuminations. Trans. Harry Zohn. New York: Schocken, 1969. 217-251.

Browne, Nick. "The Political Economy of the Television (Super) Text." American Television: New Directions in History and Theory. Ed. Nick Browne. Langhorne, PA: Harwood, 1994. 69-80.

Castells, Manuel. The Rise of the Network Society. Cambridge: Blackwell, 1996.

Douglas, Susan. Inventing American Broadcasting: 1912-1922. Baltimore: Johns Hopkins University Press, 1987.

Ellul, Jacques. Technological Society. Trans. John Wilkinson. New York: Random House, 1964.

Galbraith, John Kenneth. The Affluent Society. New York: Houghton Mifflin. 1958.

Hardt, Michael, and Antonio Negri. Empire. Cambridge: Harvard University Press, 2000.

Houston, Beverle. "Viewing Television: The Metapsychology of Endless Consumption." Quarterly Review of Film Studies 9 (Summer 1984): 183-195.

Huyssen, Andreas. "Mass Culture as Woman: Modernism's Other." Studies in Entertain- 
ment: Critical Approaches to Mass Culture. Ed. Tania Modleski. Bloomington: Indiana University Press, 1986. 188-208.

Jameson, Fredric. Postmodernism, or, the Cultural Logic of Late Capitalism. Durham: Duke University Press, 1991.

Jay, Martin. The Dialectical Imagination: A History of the Frankfurt School and the Institute of Social Research, 192.3-1950. Berkeley: University of California Press, 1996.

Joyrich, Lynne. Re-Viewing Reception: Television, Gender, and Postmodern Culture. Bloomington: Indiana University Press, 1996.

Lipsitz, George. "The Meaning of Memory: Family, Class and Ethnicity in Early Network Television." American Television: New Directions in History and Theory. Ed. Nick Browne. Langhorne, PA: Harwood, 1994. 37-65.

Lyotard, Jean-François. The Postmodern Condition. Trans. Brian Massumi et al. Minneapolis: University of Minnesota Press, 1984.

Marchand, Roland. Advertising and the American Dream: Making Way for Modernity, 1920-1940. Berkeley: University of California Press, 1985.

Marcuse, Herbert. One-Dimensional Man. Boston: Beacon, 1964.

McKendrick, Neil, et al., eds. The Birth of Consumer Society: The Commercialization of Eighteenth-Century England. Bloomington: Indiana University Press, 1982.

McLuhan, Marshall. The Gutenberg Galaxy: The Making of Typographic Man. Toronto: University of Toronto Press, 1962.

—. Understanding Media: The Extensions of Man. New York: McGraw-Hill, 1964.

Modleski, Tania, ed. Studies in Entertainment. Bloomington: Indiana University Press, 1986.

Morse, Margaret. Virtualities: Television, Media Art, and Cyberculture. Bloomington: Indiana University Press, 1998.

Poster, Mark. Existential Marxism in Postwar France: From Sartre to Althusser. Princeton: Princeton University Press, 1975.

Richards, Thomas. The Commodity Culture of Victorian England: Advertising and Spectacle, 1851-1914. Stanford: Stanford University Press, 1990.

Riesman, David. The Lonely Crowd. New Haven: Yale University Press, 1950.

Spigel, Lynn. Make Room for TV: Television and the Family Ideal in Postwar America. Chicago: University of Chicago Press, 1992.

Warner, Michael. The Letters of the Republic: Publication and the Public Sphere in Eighteenth-Century America. Cambridge: Harvard University Press, 1992.

Williams, Raymond. Television: Technology and Cultural Form. London: Fontana, 1974. 